\title{
A HELY SZELLEME, A TELEPÜLÉSIMAGE ÉS TELEPÜLÉSMARKETING
}

\author{
(The Spirit of Place, Settlement Image and Settlement Marketing)
}

\section{JANKÓ FERENC}

Kulcsszavak:

hely szelleme regionális tudomány településimage településmarketing

A hely szelleme széles körben elterjedt, kizárólag egy tudományhoz, tudományághoz nem kötödö kifejezés. A szépirodalmi témájú irásokon túl megtalálható a posztmodern építészet és a szociológia fogalomrendszerében is. A dolgozat célja az egyes fogalmi megközelítések bemutatása mellett a genius loci értelmezése a regionális tudomány rendszerében, illetve jelentéstartalmának elválasztása a behaviorista földrajz „,elepülésimage” és „, sense of place” (helyérzet) fogalmától.

\section{Bevezetés}

Tanulmányunk a „hely szelleme”, a ,genius loci” fogalomkörét elemzi. Célunk ezen összetett, sokrétủ kifejezés magyarázata, továbbá a regionális tudomány és a földrajztudomány fogalomrendszerébe való illesztése, és az ennek nyomán fellépő, feltáruló kapcsolatok elemzése. Írásunk terjedelmi korlátai miatt természetesen nem térhetünk ki e kapcsolatrendszer minden elemére (így például kimarad elemzésünkbỏl az egyik legaktuálisabb viszony, a globalizáció és a hely szellemének összefüggésrendszere).

\section{Genius loci}

\section{A fogalom eredete: a Római Birodalom kora és a római mitológia}

A fogalom eredetének tisztázásához a genius szó jelentését kell elöször bemutatnunk. E latin szó a gens - nemzetség, és a gigno - nemzeni, szülni, teremteni szavakkal rokonitható, illetve szavakból eredeztethetö. A geniust eredetileg a nemzetségek isteneként tisztelték. Majd különböző jelentés-módosulásokon ment át. Így később a család urának, a férfi belsỏ erőinek, képességeinek megtestesítójét látták benne. Hozzá imádkoztak a családfő születése napján. A család, a nemzetség szaporodási képességét, önfenntartó erejét vigyázta. A genius női megfelelője a junó (iunó) volt. Kultuszának minden formájában kígyó alakban képzelték el.

$\mathrm{Az}$ individualizmus terjedésével és a görög daimón, összellem görög felfogásának térhódításával fokozatosan az egyén természetes vágyainak, kívánságainak megtestesítője lett, a belső tulajdonságok megszemélyesítóje, aki együtt születik az emberrel, irányítja a cselekedeteit, az ember halála után pedig a föld közelében bolyong, vagy egyesül az istenekkel. 
A szabad emberek a saját, a rabszolgák az uruk geniusára esküdtek fel. A geniusnak fogadalmi feliratokat, oltárokat készítettek. A fogalom jelentésének kiteljesedésével már az egyes helyeknek, városoknak, utcáknak, tereknek, továbbá népeknek, testületeknek, katonai szervezeteknek is lehetett geniusa. Így a római nép geniusának szobra a Forum Romanumon állt, Róma geniusának pedig egy pajzsot szenteltek a Capitoliumon. A genius vallásos szerepe különösen a császárkorban erősödött meg, ekkor a császárok geniusának kultusza is nagyon jelentős volt (Trencsényi-Waldapfel 1983; Tokarev 1988; Élesztős 1993; Széky 1994).

A régi római jelentés a genius loci kifejezéssel tehát a hely szentségét hangsúlyozta, ami abban jutott kifejezésre, hogy az emberek vagy egy különleges istenség számára szentelték meg a helyet, vagy oltárt állítottak ott egy helyi istenségnek (Loukaki 1997).

Példákat a római mitológiából vehetünk. Aeneas, a trójai mondakör hőse így szólt atyja sírjánál: „Üdvöz légy, szentséges atyám, legyetek üdvözölve ismét felkeresett hamvak, atyám szelleme, római árnyak! Hát nem adta meg a sors, hogy veled keressem fel Itália határait, a végzet által nekünk rendelt mezőket $\mathrm{s}$ Ansonia még ismeretlen folyóját, a Tiberist. Ahogy kimondta, hétszeresen tekergőző kígyó csúszott elö a szentélyböl, az oltárok között, szelíden kóstolgatva az áldozati ételeket, majd eltủnt a sírhalom mögött. Aeneas nem tudta, hogy a hely geniusát vagy atyja szellemét tisztelje-e a kígyóban, de mindenesetre az atyja tiszteletére rendezett áldozati szertartást annál nagyobb fénnyel igyekezett megtartani" (TrencsényiWaldapfel 1983, 288). Amikor pedig a latiumi partokhoz ért, hogy az istenek akarata szerinti otthonára leljen, ekképpen szólt, cselekedett: „Üdvöz légy föld, melyet nekem szánt a Végzet, s legyetek üdvözölve Trója hü Penatesei! Itt van az otthon, ez a hazánk! - s halántékát lombos ággal koszorúzva az istenekhez fordult imájával; elsőként a hely geniusát, Tellust: a földet, a vidék nympháját, és a még ismeretlen folyóvizeket szólította" (Trencsényi-Waldapfel 1983, 292).

\section{Transzcendencia, szakrális helyek, vallás}

Az ember vallásos, szakrális élete az ősidőktől fogva létezik, a hely szellemének eredeti jelentése is ehhez kapcsolódik. Világunkban a szakralitás, transzcendencia legtöbb helyen ma is központi szerepet játszik az egyének, közösségek életrendjének kialakitásában. A genius loci fogalma e szemszögböl úgy magyarázható, hogy az ösi szakrális helyek szentsége hasonló - bár valószínüleg jóval gazdagabb érzéseket válthatott ki adott korok emberéből, mint manapság a hely geniusának felismerése, megértése.

A szent helyek létéböl egyenesen következik, hogy voltak/vannak különösebb jelentéstartalom nélküli helyek is, a tér tehát szent terek és világi terek mozaikjára bontható. Ez Eliade (1996) szemléletében világosan tükröződik, aki szerint a tér szent és profán térre osztható, előbbire jellemzö a szakrális erővonalak kirajzolta inhomogenitás, utóbbi pedig homogén, sok, többé-kevésbé semleges hely formátlan tömege. Eliade sejteti a hely szelleme fogalmának beilleszkedését térfelfogásába, 
amikor azt mondja, hogy a profán térélményre is jellemzőek az inhomogenitások, a magánvilágok szent helyei, amelyek a profán ember kriptovallásos viselkedése révén alakulnak ki.

Nemcsak a tér van hatással a vallásra, hanem a vallás is a térre. A valláshoz hasonlóan a személyes motívumok is szakralizálhatják a teret, továbbá az etnikai identitás, a nemzethez tartozás is müködö szakrális tereket hoz létre (Bartha 2000).

A vallásos tér-profán tér kettőssége máig erösen él a néphitben. Azonban e kettősség keveredik, át- és átfedi egymást. Az emberek lakhelye elsődlegesen a falu, a lakott ház, illetve helyiség. A senki földje, a falu határa, a házon kívüli térségek, a lakatlan házak, helyiségek pedig a természetfeletti lények birodalma. A tér duális rendszere az idő duális rendszerével múködik együtt, így a nappal-éjszaka duál is elválasztja a két térrészt. Szentséget hordoz maga a lakóház, a tisztaszoba is. A periféria sem csak a „túlvilág kapuja”, a gonosz szellemek tanyája, az erőszakos halállal meghaltak, koraszülöttek, kereszteletlenek temetöhelye, hanem szent hely is - ezt a rómaiakig, etruszkokig, keltákig is visszavezethetően az ott emelt keresztek, kápolnák, templomok, temetők bizonyítják (Pócs 1983).

Hasonló gondolatokat fogalmaz meg Meggyesi (1999): „Az archaikus ember számára a tér sem homogén. A tér inhomogenitását a természetben immanens, de láthatatlan erök és szellemek jelenléte hozta létre, amit a rómaiak genius locinak neveztek. A tér spirituális eröinek, erőtereinek felismerése különleges tudást igényelt. A teret maga az ember is megszentelheti, azáltal, hogy vándorlásai során az ösök sírját, késöbb prófétáinak, szentjeinek tartózkodási helyét megjelölte. A tér megszentelt helyei a késöbbi szekuláris építmények csirrái, így egy szikla, üreg, barlang, kuilönleges, esetleg égi eredetü kö vagy kőhalom, domb, hegycsúcs, tisztás, forrás, fa is lehettek. A megszentelt helyek fontos szerepet játszhattak az emberré válásban. Az állandóságot képviselték az emberi lét, térbeni és idöbeni változásaival szemben. A világnak egyidejüleg több közepe is lehet: ez a tér inhomogenitásának alapja." (Meggyesi 1999, 65-66)

Kettéválasztható tehát az emberen kívüli okokból szentté vált hely és az ember által, szubjektívan megszentelt hely is. Míg az elözöbe tartozik egy villámcsapás sújtotta évszázados fa, egy „égig éró” hegy (pl. Csomolungma), egy meteorit, utóbbiak közé sorolhatók a varázslók, sámánok által megszentelt barlangok, a temetö, de az egyén számára saját születési helye is.

Mumford (1985) a város kialakulása szempontjából közelít a kérdéshez: „Az őskökorszaki ember képszerü vándorlásai során elsöként a halottaknak keresett állandó lakhelyet: barlangot, körakással jelzett halmot, kollektív sírdombot. Olyan jelek voltak ezek, amelyekhez az élök feltehetöleg idönként vissza-visszatértek, hogy érintkezzenek az ösök szellemével, vagy kiengeszteljék azokat. [...] A holtak városa idöben megelözi az élök városát: bizonyos értelemben előfutára, söt szinte magva minden eleven városnak. [...] A város elsö csírája tehát a szertartásos összejövetelek helyeként jelenik meg, amely egyben zarándoklatok célja is: olyan hely, ahová bizonyos évszakokban újra meg újra visszatérnek a nagycsalád - vagy kláncsoportok, mert a város esetleges természeti elönye mellett bizonyos 'szellemi' 
vagy természetfölötti eröket összpontosit, olyan eröket, amelyek hathatósabbak és tartósabbak, kozmikusabb jelentöségüek, mint az élet közönséges folyamatai." (Mumford 1985, 13-14, 17)

Hamvas (1988a) némileg másképp eredezteti a városokat - bár e kérdés dolgozatunk szempontjából irreleváns. A közösség kezdeti létformájånak tartja a városokat; minden nép rendelkezett az égi város mintaképével: ilyen például a hinduk Brahmapuraja, a palesztinok Égi Jeruzsáleme. A város kezdetben az égben volt, anyagtalan szellemi őskép, $\mathrm{s}$ az első embereket a városépítésre a szellemi erők tanították meg. A város másik analógiája az ember maga, a bennưnk rejlő szellemváros, a belső „lélek-város" mása. Mumforddal ellentétben azt mondja, hogy a városból lett a falu, más tekintetben azonban hasonló véleményen vannak:

„A város nem a tanyából és a faluból keletkezett, hanem ideája a szellemvilágból szállt alá, s a falu és a tanya készült a város mintájára. [...] A város létének és virágzásának legelső feltétele éppen a szakrális hely, ahol égi jelekkel ellátott hegy állt, forrás fakadt, vagy folyó folyt, vagy tengeri öböl nyílt. [...] A föld az asszony, a szellem a férfi. [...] A várost nem hatalommal kell kormányozni, hanem szellemmel vezetni. Ez az átszellemült létnek megfelelő uralmi eszköz. Ezt nevezték a régiek ars regiának, királyi müvészetnek, mert nem szigor, nem büntetés volt, hanem magas tudás: mủvészet. Ars regia csak ott lehetséges, ahol az anyagi és földi erök korlátlan hatalma megszủnt. Vidéken, ahol az úr a föld, a falu, a gazdaság, ott lehetetlen, mert ott az anyagi és földi erök hatalma teljes. [...] A városban az anyagi és földi erök hatalma háttérbe szorul: a város a szent hely, amelyet a szent fal vesz köruil, és a várost az utcák kövezete az anyagi földről levágja. [...] Nem agyag többé." (Hamvas 1988a, 506-512)

„A falu szükségközösség. A természeti kényszer teremti és a közösség itt tudattalan, vagyis nem személyes. A tudatosan vállalt közös élet a város. A küzdelem, hogy a nép szakrális közösség legyen, a történet. A sors teljességéhez azonban még valami hozzátartozik, a szellem." (Hamvas 1988b, 60)

E gondolatok mentén látható, hogy a szent helyek hogyan kapcsolódnak össze a városok fogalmával. Miként igazi településnek a várost tartjuk, úgy elsősorban egy városra gondolunk a genius loci kapcsán.

A Mumford és Hamvas által felvázolt filozófia mentén halad tovább Meggyesi is: „Az emberi környezet eredetileg szakrálisan meghatározott természetes és épített elemei a későbbi építmények archetípusaivá lettek, hasonlóan ahhoz, hogy az első megjelölt helyek és hajlékok archetípusát égi konstellációk szolgáltatták. Az építésnek a megjelölt hely megszentelésével az égi mintákhoz, a genius loci kiengesztelésével a konkrét földrajzi helyhez, az építmények tipológiájával pedig az ösök által létrehozott archetípusokhoz kellett valamilyen formában viszonyulni." (Meggyesi 1999, 66)

Az eddigieket áttekintve egyértelmủnek látszik, hogy a világ szekularizálódásával a helyek szentségébỏl adódó tisztelet, a hely vallásos erejének átélése profánabb tárgyat és egyben formát kapott, s szakrális tartalom nélküli tiszteletté, csodálattá alakult. 


\section{Bölcseleti, irodalmi megközelitések}

Bánk (1997) szerint a hely szelleme „ma azt a sajátos szellemiséget, légkört jelenti, amelyet egy-egy nevezetes hely sugároz magából." Bakos (1994) pedig azt a meghatározást adja, hogy a genius loci „egy bizonyos helyen uralkodó, onnan kisugárzó szellem.” A genius szóra pedig többek közt a következő definíciót közli: „szellemi al kotóképesség, alkotó ero."

Már ezen megfogalmazások alapján is tehetö néhány fontos megállapítás. A hangsúly a szellemiségen, a sajátos légkörön van, amely kisugárzik egy adott helybool. Ennek értelmében egyrészt rögzíthetjük, hogy a hely szelleme csakis és kizárólag adott helyen érezhető, figyelembe véve a hely elhatárolhatóságát, a más helyektől való elkülönítés lehetőségét. Másrészt a hely szelleme egy különleges erö, egy szellemi erő, amelyet Hamvas Béla a következőképpen fogalmaz meg: „A szellem nem tudás, nem intelligencia, nem müveltség, nem okosság, a szellem a világelemek közül az egyetlen, amely számára nincs lehetetlen, amely bármit akar, meg tudja tenni. Szellem nélkül élni reménytelen lenne, mert a szellem a világelemek közül a teremtö." (Hamvas 1988b, 60)

Ezért, amikor a legtöbb író egy adott hely, legtöbbször város géniuszáról ír, azokat az érzéseit önti mondatokba, amelyeket a város kiváltott belőle, azokat a cselekvéseket, amiket szellemisége alatt tett, vagy részletezi a város kinézetét, történelmét, felsorolja szülötteit, vagy ahogy a helybeli emberek viselkednek, ahogy életüket szervezik, vélhetöen tudat alatt a genius által is vezérelve. Konrád (1989) szerint a hely szellemének egyenesen hatása van az emberi fejlődésre. Baksa (2002) megfogalmazásából a hely szellemének ,erő” voltára hívhatjuk fel a figyelmet, amely a cselekvésben is befolyásolhat. Másrészt szintén jó példa a történelmi személyiségek jelentös hatása a helyek szellemiségének befolyásolásában: „Miért választotta Ferenczy Viktor kutatási témájául Jedlik Ányost? [...] A válaszok egyike lehet a genius loci, a hely szellemének hatása. Abban az intézményben tanult és tanított, annak a közösségnek a tagja volt, amelynek Jedlik Ányos. Szükíthetjük a teret a szertárra, ahol féltö gondját viselte néhány Jedlik-relikviának. A rendházban tisztelet övezte azt a szobát is, ahol Jedlik nyugdíjas éveit töltötte. A hely szelleme nagy erö." (Baksa 2002, 75)

Mandics (1996) vagy Orosz (2001) egy-egy település kapcsán jellemzi az ottani embereket, s szintén felsorolja a város és környéke híres szülötteit. Hamvas (1988b), amikor a Kárpát-medence öt tájának szellemiségéről ír, sorra veszi többek között a történelmi fejlődés sajátosságait, a társadalmi, gazdasági viszonyokat, a kulturális élet egyes jellemzőit, egyáltalán az élet milyenségét, páratlan intuíciói, gazdag kifejezési eszköztára segítségével magukat a szellemiségeket, a géniuszokat is jellemzi.

Vekerdi (1996) rendszerezése szerint a genius loci többféle szövegkörnyezetben megjelenhet: a szülöföld, ábrázolások, táj-élmény, temető, vesztőhely stb. kapcsán. Figyelmeztet, hogy a helynek nemcsak jó, hanem rossz szelleme is van. Megközelítése egyfelől tehát a genius, mint „erő” felől történik. Definíciója meglehetősen 
széles - saját véleményünkhöz egyébként nagyon közeli. „Játékos” meghatározása - genius loci szelleme - egyrészt példázza a szellem szó szerteágazó jelentését, másrészt véleményünk szerint Vekerdi itt olyasféle dologra gondol, amit az angolszász szakirodalom "sense of place" néven emleget (bövebben lásd a "Sense of place” fejezetben): „Kézzelfogható részletekböl, kicsikböl és nagyokból, személyesekböl csakúgy, mint közérdeküekböl és közismertekböl tevödik össze a genius loci. A hely Géniuszához, amely mint minden Géniusz önmagában igencsak megfoghatatlan, éppen ezek a kisebb-nagyobb, jelentéktelenebb és fontosabb, de mindig kézzelfogható reális részletek teszik hozzá a lelket. Így keletkezik a genius loci szelleme, egy fogalomról alkotott fogalom. Amelyben a világtörténelem és a helyi történelem, a természeti és az épitett táj keveredik, jobbára elválaszthatatlanul és felfejthetetlenül emlékek, ismeretek, érzések, várakozások, vonzások és választások meghatározhatatlan halmazával. [...] A hely szelleme örzi és segíti az embert, aki viszont megérzi, éli, kifejezi, megérti, és ezáltal erösiti a hely szellemét." (Vekerdi 1996, 37-41)

Bánlaky (1992) mondataiban szintén a történelmiség, a természeti és épített környezet, illetve az egyén szubjektivitásának alapvetőségét figyelhetjük meg: „Keresem, elsö benyomásként az utcákból, kövekböl, házakból, fákból, a legkülsö látványelemekböl összegzödö atmoszférát. Felérek természetesen a Várhoz. Csöndes, kora öszi délelött, turisták nincsenek, magam bóklászom a falak között. És akkor megérint valami. A Vár még álló, ezeréves falai között járkálva én, romantikus álmodozó, a tudós szociológus álruhájában, a gyermek Vajk csilingelö kacagását vélem a falak mögül hallani, majd meg az érett férfi bölcs törvénykezését, s mintha visszhangoznák a kövek a fiát, müve-folytató reményét vesztett öregember keserves jajongását. [...] Az a vár ott van Esztergomban. VAN, jelen idejüen, a mindennapokban. Nem emlék és múlt csupán ( $a z$ is persze), része, összetevö eleme a város mai arculatának. És talán nemcsak a kö, a látvány, hanem ennél jóval több: a szellem is." (Bánlaky 1992, 11-13)

\section{Építészeti megközelítések}

A posztmodern kor városépítészeti elméletei között megtalálható a helyet, a hely szellemét középpontba állító elmélet is. Ennek egyik elméleti megalapozója Norberg-Schultz, aki a helyet elsősorban fizikai képződménynek tekinti, így elsősorban a fizikai környezet határozza meg a hely szellemét (Holt-Jensen 1999; Lukovich 2001).

Ezen irányzat már nem csak az építészeti tér és tömegformálás szabályaival, nem csak a települések kapcsolat-hálózatainak mind jobb kialakításával foglalkozik, hanem már egy lépéssel továbbmenve az emberi igényeket, a kulturális és környezeti dimenziókat is vizsgálat alá vonja, egészen a sajátos formák és a részletek mikroszintjéig hatolva. Az emberek társadalmi és kulturális értékeit, vizuális percepcióját figyelembe vevő kontextualizmus élesen szembefordul a funkcionaliz- 
mussal. A térböl ezek szerint akkor válik hely, ha a regionális és kulturális kontextusból levezetett jelentést kap (Lukovich 2001).

A városépítész feladata már nem egyszerúen a fizikai tér manipulációja, hanem egyfajta környezeti szintézis, harmónia kialakulásának elősegítése. Eszerint a hangsúly a minimális beavatkozásokra kerül a radikális tervek helyett. A városképek mibenlétét az elsök között vizsgálja Cullen (idézi Lukovich 2001). Szerinte a városi élmények döntően vizuálisak, azonban az emberi emlékezetben lévő tapasztalatok, élmények, kapcsolatok is felszabadulnak. Ez a kapcsolatok müvészete, amely három módon gyakorolható: a szekvenciális látvány, a hely és annak szelleme, illetve az építészeti tartalom segítségével. Módszerében így az egyes helyeket komplexen feltárja, tervezésének is központi eleme a karakteres, emlékezetes helyek létrehozása. Lynch mental map kutatásai is ide sorolhatók. Lynch hangsúlyozza a városkép dinamikus elemeinek fontosságát is. A város olvashatósága, felfoghatósága szempontjából öt fontos városképi elemet különített el: útvonalak, csomópontok, jelzöpontok, szélek és körzetek. Lynch szerint a helyeknek folyamatosan kapcsolatban kell lenniük múltjukkal és jövőjükkel. Alapvető várostervezési elvei az érthetőség, felfoghatóság, a szerkezet és identitás, illetve az imázs (Lynch 1979; Lukovich 2001).

Maslow szerint (idézi Lukovich 2001; Cséfalvay 1994; Berényi 2001a) az emberi igények a következőképpen rendezödnek hierarchiába: 1. fiziológiai igények, 2. biztonsággal kapcsolatos igények, 3. hovatartozás igényei, 4. megbecsüléssel összefüggő igények, 5. önmegvalósítás igényei, 6. kognitív és esztétikai igények, 7. transzcendencia. Maslow emberi motivációs elméletébe több helyen illeszthető be a hely szellemének fogalma. A biztonsággal kapcsolatos igények egyik fajta megnyilvánulása a territoriális viselkedés, amihez a városépítészeti tervezésnek alkalmazkodni kell, elö kell segíteni a lakók azonosulását a hellyel. Hasonló következtetést lehet levonni a hovatartozás igénye kapcsán. Ez nemcsak valamilyen társadalmi formáció szintjén jöhet létre, hanem az identitás alapja lehet a hely is. A regionális identitás, a hely szellemének megteremtését az építészetnek fel kell vállalni.

Számunkra nyilvánvaló, hogy Lukovich - akaratlanul, s vétlenül - összemossa a „,sense of place” kifejezés és a hely szelleme jelentését. Elvitathatatlan, hogy a hely szelleme, mint „erő” elősegíti a helyi identitás kialakulását, azonban nem lehet egyenlőségjelet tenni a két kifejezés közé.

Sandercock (1999) modellje is köthető a hely szelleméhez kapcsolódó építészeti irányzathoz. Három városi réteg egymásra épülését mutatja be, amelyeket figyelembe kell venni a tervezés során: az emlékek, a vágyak és a szellem városa. Az emlékek nemcsak a családi, közösségi, nemzeti történelemben helyeznek el bennünket, hanem egy város felépítésében is. A városok az emlékek lerakodóhelyeinek is tekinthetök, megszövegesítik azokat. Öseink és magunk élete mind-mind valamilyen helyhez: házakhoz, városokhoz kötődnek, így értelemmel és jelentőséggel ruházzák fel azokat. Sandercock szerint a városkép az egyéni és a közösségi emlékezet raktára. A vágyak városa - a genius locihoz csak közvetetten kapcsolódóan az aktív szint a modellben. Azt fejezi ki, hogy a városi élet szüntelen találkozásokból, összejövetelekből áll, a városi környezet így örömöket és meglepetéseket okoz. 
A vágyakat, a tudatalattiakat is, fel kell ismerni, és a tervezésben elö kell segíteni megvalósulásukat. A harmadik szféra a már említett szellem városa. Ennek értelmében a városi és városon kívüli környezetünket szent és spirituális értékekkel felruházottnak észleljük, és ennek fontosságának elismeréseképpen az ember szentélyeket, templomokat épít. A városkép alkotásakor a szellem városának jelentőségét is figyelembe kell vennünk.

Az építészet szemszögéből a hely szellemének egyik központi alkotó eleme tehát a városkép. Magyarországra ezen irányzatok késéssel jutottak el. A hely szelleme fogalmára támaszkodó városépítészeti elmélet csak a rendszerváltás után bontakozhatott ki. A korábbi években a városépítészeti irodalomban a városképpel foglalkozó kutatók nehezen jutottak el - annak elsősorban esztétikai analizálásán túl - a helyi közösség életében betöltött szerepének felismeréséig (Pogány 1954; Granasztói-Pogány 1960; Székelyné Egri 1979; Gerö 1984; Kubinszky 1995).

Granasztói (1972) az elsők között fedezi fel ezeket az aspektusokat, és így rámutat, hogy a városkép, a városforma mögött bonyolult, sokrétü tartalom rejtezik, mégpedig a helyi közösség múltja, társadalmi, gazdasági viszonyai, törekvései. A városképben az ember is benne van, hiszen az fontos az azonosulása szempontjából, s a városkép alakítja is a közösségi tudatot. Felismeri azt is, hogy a városkép befogadása függ az egyén átélési képességétől, érzékelésétől, ismereteitől. E megfogalmazások mind-mind kiterjeszthetök a genius loci fogalmára is. Legújabban Tóth (2001) foglalkozik a hagyomány szerepével a városépítészetben. Hagyomány nélkül nincs modernizáció és fordítva. A hagyományos elemeket, formákat szükségesnek tartja a modern, jelenkori építészeti alkalmazásokban, azonban figyelmeztet, hogy ezek másolása, direkt eszközökkel való megjelenítése is káros, retrográd folyamatokat indíthat el. Másfelöl a helyi kötődés hiánya a technikai civilizációból kifelejti az embert, az építészeti csoda hủvös, ember nélküli eleganciát fog sugározni. Ezért egyensúlyban kell tartani a két törekvést; lehet illeszkedni a nemzetközi trendekhez, ki lehet választani a funkciónak legjobban megfelelö, legkorszerübb technikai megoldásokat, de mindezek mellett finom áttételekkel, érzékeny utalásokkal meg kell jeleníteni a genius loci lényegét.

Loukaki (1997) több eltérő szempontot, illetve magyarázatot mutat be a genius loci fogalmára. Áttekintése - az előbbiektől némileg eltéröen - alapvetően a müvészi ábrázolás, kifejezés szemszögéből történik. Szerinte a hely szellemének jelentése mindenekelött attól függ, hogy a történelmet szinkronikusan - vagyis örökös körforgásként, önmagát ismétlőként - fogjuk fel, vagy pedig diakronikusan - az időben folyamatosan fejlődő, változó jelenségként. A hely szellemének előbbi olvasatában az emberek a környezetet változatlannak tételezik fel (Norberg-Schulzot idézi Loukaki 1997). A történelmi fejlödés figyelmen kívül hagyása azonban téves következtetések levonásához vezethet. A történelem utóbbi felfogásában a hely szelleme a korszellemnek megfelelően, az embernek a környezethez való viszonyának függvényében változik.

A genius loci értelmezése másrészt attól is függ, hogy a kultúrát, a környezetet és a mitológiát összefüggőnek tételezzük-e fel. Az építészek általános hozzáállása 
szerint nincs meg a folytonosság, az emberi beavatkozás az elsődleges, a tájképi változások az építészeti tervezés által megszabott adaptációk csupán. Harmadrészt a hely szellemének megértése az egyetemes és az egyedi közötti adott helyen, adott időben történő kölcsönhatások különféle magyarázataitól is függ. Az egyetemességet sokszor a morfológia problémájaként említik, mivel társadalom-szervezeti vagy állapotbeli hasonlóságot okoz. Itt sem mindegy, hogy szinkronikus vagy diakronikus szemlélettel tekintünk-e a problémára. Az utóbbit nézve valaki a világ változásait egy valamiféle világszellem hatalma alatt állónak látja, míg mások hisznek a normális emberi folyamatok irányítása alatt végbemenỏ történelmi fejlődésben. Az általánossá váló morfológiai megoldások így értelmezhetőek a közönséges emberi szükségletek megvalósulásaként. Ezeket sokan a genius locival azonosítják. Az építészet elemezhető egyetemesen, az emberiség kollektív tudata, tradíciói alapján, a mitológia segítségével is. Valaki a törzsi, a családi szellemiséget tanulmányozza. Főleg a keleti kultúrákban elfogadott, hogy minden épitészeti szimbólumnak van valamilyen metafizikai alapja.

Az építészeti megközelítések egyrészt tehát felhívják a figyelmet a városkép fontosságára. Másrészt meghatározó a szubjektum, jelen esetben az építész szerepe, mind a genius loci megértésében, mind a szellemiség kifejezésében, tolmácsolásában, hiszen ezáltal ők maguk is befolyásolják a genius locit.

\section{Szociológiai megközelítések}

A helyi társadalmakat is kutató szociológia nézőterébe szintén bekerülhet a hely szellemének fogalma. Erre - sajnos csak - kevés példát sikerült találnunk, azonban ezek is nagyszerủen példázzák, hogy az alapvetően a társadalmat kutatási célként megjelölő szociológia tudománya, az építészethez hasonlóan, szakterületének fó tárgya felöl közelít szinte bármely kérdéshez, így a genius loci fogalmához is. „Minden városra jellemzö a hely szelleme. Ahol ez hiányzik, ott városi társadalom sincs, csak különbözö rangú, életkorú, státuszú, közösségeit elveszített, integritását feladó populáció jelenlétét regisztrálhatjuk. A genius loci az, amitöl egy város páratlan, egyedi. További kérdés, hogy miben ragadható meg a hely szelleme? Szerintünk az magában foglalja a város polgárainak (lakóinak) gondolkodásmódját, viselkedését, kultúráját, ez utóbbin belül politikai kultúráját, és ha van ilyen, a várost uraló ideológiát is. (A kilencvenes években ezt már úgy mondanánk, hogy magában foglalja a város meghatározó szellemi irányzatait is.) A hely szelleme elöször is megkuilönbözteti a várost az összes többitöl, reprezentálja sajátosságait. Másodszor ötvözi, magába süríti a helyi társadalom tradícióit és jelenlegi állapotát. A város ezáltal minősülhet rebellisnek vagy megalkuvónak, vélt vagy valóságos sérelmeit kezelni (megoldani) képesnek, vagy azoktól szabadulni képtelennek, haladó szellemünek vagy konzervatívnak és így tovább. Megforditva: a város, a hely szellemisége motiváló tényezojje az állampolgárok magatartásának, mentalitásának, kultúrájának. Ez az, amihez a beköltözönek alkalmazkodni illik." (Böhm-Táll 1992, 11) 
Alapvető állítás, hogy a hely szelleme közösség-meghatározó és közösségdefiniáló tényező, feltétele a helyi identitásnak (Böhm 2000). Kiemelt a genius loci azon szerepe is, amely az adott várost a többitöl megkülönbözteti. Ezek új szempontok eddigi megállapításainkhoz képest. A szociológiai szemléletből adódóan elsősorban a társadalom hordozza, kommunikálja a hely szellemét, s a társadalom az, amire a hely szelleme elsősorban hatást gyakorol. Megfogalmazásukból így talán nem véletlenül hiányzik az épített környezet és a természeti táj szerepének felismerése, illetve megemlítése.

\section{Összegzés}

A különböző megközelítések áttekintése után elérkeztünk ahhoz a ponthoz, hogy összegezzük a genius loci fogalmát, jelentésrendszerét.

Mint a hivatkozások, illetve az idézetek is mutatják, a hely szelleme fogalmának eredeti, római jelentése elveszett, illetve átalakult, alapvetỏen a géniusz, a szellem fogalmának szélesedésével, megváltozásával. Mondhatjuk azt, hogy a fogalom maga is szekularizálódott, tehát javarészt elvesztette vallási töltetét. Ez értelmezhető úgy is, mint ahogy Eliade sugallja, hogy a hely szelleme mai jelentésében az emberek kriptovallásos viselkedéséhez köthetö. De másfelöl arra is gondolhatunk, hogy a „szent" fogalom jelentése szintén tágult, világi jelentéstöbbletekre is szert tett, így egy hely szentsége sem csupán vallási értelemben értelmezhető.

A hely szellemisége tehát alapvetően egy erö, egy szellemi erö, amelyet adott hely sugároz magából. Ez az erỏ helyhez kötött, olyannyira, hogy a hely szellemét csak akkor érezhetjük, ha a helyszínen tartózkodunk! Beszélhetünk róla, emlékezetböl írhatunk róla bárhol, de érezni közvetlenúl csak adott helyen, helyben lehet. Ez az egyik leglényegesebb tulajdonsága e fogalomnak: a szó szerinti helyhez kötöttség.

A hely szellemiségének fő tulajdonsága - mivel erőnek definiáltuk - az, hogy aki azt megérzi, akit az áthat, ,annak szellemében” cselekedhet további életében vagy bizonyos helyzetekben. Mint ahogy Hamvas mondja, a szellem teremtő erő, ami az embert általában jó útra vezetí, de ahogy Vekerdi figyelmeztet - és ezt szem elött kell tartanunk - a hely szelleme lehet rossz szellem is, még ha ezt a jelentéstartalmat az általános vélekedések mellözik is.

A hely szelleme nemcsak mint adott helyhez szorosan kötỏdöt, például bizonyos város lakóját érinthet meg, hanem mint a helyre érkező idegent is. A híres Maslowpiramis legfelső szintjein található kognitiv, esztétikai, és akár transzcendentális igények, törekvések megvalósításában a hely szelleme is eszközzé válhat.

A hely alapvetôen kétféle hely lehet. Először is természeti táj vagy tájelem, mint például egy hegy, domb, egy idős fa, egy különleges szikla, barlang stb. Az efféle „helyek” szelleméröl manapság ritkábban esik szó. Elmondható, hogy ezek géniusza még sokkal inkább közelebb van a genius loci eredeti jelentéséhez, sokkal inkább kötődhet, kötödik a transzcendenciához, a különböző vallási viselkedésekhez. De mindezek mellett szintén lehet e dolgoknak, helyeknek világi szellemisége is. 
Másodszor a hely lehet ember által átalakított, épített környezet, amelyet érzékelhetünk a természeti tájban vagy anélkül, egyszerübb kifejezéssel élve kultúrtájként (Berényi 2001b). Az épített környezet az áttekintett irodalomban legtöbbször város vagy annak bármekkora része, helye, de természetesen lehet falu is. Az épített környezeten belül nagyon fontos a városkép vagy falukép szerepe, a különbözó építészeti korok stílusjegyeit magán viselö épületek által képzett együttesek, kompozíciók, az utcák, a terek rendszere, szerveződése, mint a genius loci meghatározói, illetve hordozói, azt kommunikáló elemei. A városkép a helynek nemcsak múltbeli, hanem jelenbeli szellemiségét is hordozza.

Bizonyos mértékig - többnyire csak elméletileg - szétválasztható a hely jelenbeli és múltbeli szellemisége. Nagyon ritkán érezhetjük azt bizonyos helyek esetében, hogy a hely, például a város jelenbeli szellemisége, amit az emberek életmódja, viselkedése sugall nincs összhangban a városkép által sugárzott szellemiséggel. Ez nagy lakosságcserék után fordulhat elö, de elegendö lehet egy rendszerváltás, a „korszellem” hirtelen megváltozása is. Normális esetben ez azonban csak elméletileg tehetó meg, s organikus fejlỏdésen átment helyek, települések esetében a városkép, a természeti környezet, a helyi emberek életmódja egységes szellemiséget sugároz, ami azt jelenti, hogy a jelen szerves folytatása a múltnak. Magyarországi példákra gondolva a zürzavaros történelem miatt az épített környezet és a lakosság, a helyi életforma gyakran nincs párhuzamban, s ez megnehezíti a hely szellemének kibontakozását.

A hely szellemének ,hordozói” lehetnek tehát egyrészt az „élettelen”, pontosabban ember nélküli összetevök. Másrészt ott van, illetve él az ember, a társadalom, a hely társadalma, közössége, amely szintén a genius loci hordozojának tekinthető. A helyi társadalom még akkor is közvetíti a hely szellemét, ha annak nincs tudatában, ha a fogalmat nem is ismeri. Fontosnak tekinthetjük viszont azt, hogy a helyi társadalomnak bizonyos fokú integráltságot el kell érnie, tehát az egyes emberek életmódjának, életrendjének több metszéspontja kell, hogy legyen. Bár e kérdéskör úgy is értelmezhetö, hogy az emberek viselkedésének sokfélesége, tarkasága szintén ki fog alakítani egy sajátos szellemiséget. Ez a kétféle szint olymódon magyarázható, hogy amíg a hely szelleme mint erö nem tudja bizonyos fokig irányítani a helyi lakosok életét, addig azok csupán befolyásolói annak, amikor viszont a szellemiség áthatja a közösséget, az maga is termelöjévé, közvetítöjévé válik a genius locinak.

Ez az a szemszög, amiböl kiindulva kritizálható Böhm és Táll azon felvetése, hogy a hely szellemét etalonnak tekinti a helyi közösségek kiformálódásához, illetve legitimitásához. Értelmezhetö-e egészében a szellemisége egy tarka nagyvárosi metropolisz nagyfokú szegregáltságot mutató, különféle etnikumok sokaságából álló halmazának? Mert megkérdőjelezhetö a különböző csoportok, közösségek egy nagy, összvárosi közösségé integrálódása is.

Itt érkezünk el ahhoz a ponthoz, hogy feltegyük a kérdést, miszerint minden helynek van-e szelleme, szellemisége? Véleményünk szerint, ha egy hely részeinek (melyek szintén helyek!) esetében beszélhetünk a genius lociról, akkor maga a hely esetében is megtehetjük ezt, mondhatjuk, hogy a šellemiségek egy magasabb szin- 
ten összeadódnak. Viszont ha egy adott hely esetében beszélhetünk a hely szelleméröl, még korántsem biztos, hogy ezt megtehetjük a hely részeinek esetében.

Eddig próbáltuk megkerülni, de most végre utalhatunk rá, hogy a hely szelleme, annak felfogása sokban függ a szubjektumtól. Nemcsak ismereteinktöl, tudásunktól függ, hanem lelkiállapotunktól, elvárásainktól, hangulatunktól, beleérzö, intuitív képességeinktöl is, amelyeken a szellemiség, mint egyfajta szürön halad át, s nyeri el aktuális formáját. A hely szellemének számtalan objektív - elvileg mindenki számára adott - alkotórésze van, de azokat korántsem biztos, hogy mindenki észreveszi, így elöfordulhat, hogy egy hely valakit megérint szellemisége által, valakit pedig nem. A település, a város szellemiségét (is) tudatosan kereső embertípus a „flaneur" (Konrád 1989).

Ez különösképpen vonatkozhat a legfontosabb történelmi eseményeknek adott helyre vonatkozó hihetetlen széles tárházára. Míg például az épített tér, a városkép mindenki számára „elérhetőek”, megragadhatóak, a történelem ismeretei tudásfüggök is. Aki nem tud semmit a helyröl, ahova érkezett, az csupán a városképet és az emberek életrendjét fogja látni, s így keveset érez meg a hely szellemiségéből. Az ismeretek leggyakrabban a kommunikáció különböző formái által válnak tudássá. A kommunikáció tekinthető így a hely szellemének a környezet és az ember után a harmadik hordozó, közvetítő elemnek. A kommunikáció különböző írott és elektronikus fajtái (könyvek, média, film stb.) legtöbbször nincsenek helyhez kötve, azok az ember tudatába beépülve, az emberrel együtt kerülnek az adott helyre, ahol elöhívhatóak.

A korábbi fejezetekben, s az összegzés során is többször láthattuk, hogy a hely szellemének alapvetỏen történelmi bázisa van. Citálható Descartes értelmezése az emberi szellemröl, amely az ember halála után tovább él (Ryle 1974). Ugyanígy tekinthetjük - a valaha az adott helyen élt, alkotott stb. emberek szelleme mellett a különbözö események máig gyürüző szellemiségét. A történelmiség fontos képviselöi tehát a valamikori helyi, híres vagy közemberek, illetve események, történések, amelyek emléket hagytak az utókor számára (gondoljunk Sandercock ,emlékek városára”). Ezen „emlékek” nem csupán az emberek emlékezetében rögzülhetnek, hanem tárgyi, írott emlékek is lehetnek, mint a helyi szellemiség alkotásai: szobrok, festmények, irodalmi alkotások, s a már említett épített környezet.

De a hely szelleme értelmezhetö sokkal tágabban, személyes szubjektív elemekkel is. Azokkal az elsősorban történelmi elemekkel, amelyek velünk vagy családunk szük körével történtek meg az adott helyen. De ilyenek lehetnek az illatok és a hangok is.

A történelmi múlt hordozója lehet a hely neve (Kovacsics 2001), s így a név öszszefonódhat a hely géniuszával is. (A helyiségnév fogalma már átvezet a helyek image-ének kérdésköréhez.) Ennek kapcsán Hamvas a következöképpen ír: „A legtöbb embernek helyneve van. Ez a jegy rajta, megmondja honnan jött. A géniusz nevét viseli. A név pedig valami, amit nem lehet másképpen mondani. Varázslat, amely olyasmit nyit meg, amit másképpen nem lehet. A hely az, ameddig a név varázsa elér." (Hamvas 1988b, 57) 
Jankó Ferenc :

A hely szelleme, a településimage és településmarketing.

Tér és Társadalom 16. évf. 2002/4. 39-62. p.

Eddig csak jelen időben beszéltünk a hely szelleméről, pedig az az idő előrehaladásával folyamatosan változik, ahogy az egyes időegységek, s azok történései is történelemmé válnak. Már néhányszor említésre került a korszellem fogalma. Ez szorosan összefügg a hely szellemével. A korszellem mindig adott kornak az élethez, a világhoz való viszonyát fejezi ki, a kor és annak embere ennek megfelelően cselekszik, formálja környezetét, viszonyul embertársaihoz stb. A hely szelleme úgy is értelmezhetö, hogy a helyen mindig, minden kor szellemisége is lerakódik, erösebben vagy gyengébben, látható és láthatatlan bélyegeket, nyomokat hagyva a helyen. Ezek összeadódva, összekeveredve a jelenben mindig többé-kevésbé egységes szellemiségként mutatkoznak. A különböző korok szelleme nem azonos erejü, ez függ az adott kor időtartamától is, az erősebbek elnyomják, elfedik a gyengéket.

\section{1. ÁBRA}

A hely szelleme jelentésrendszere

(The Structure of Meanings of ,Genius Loci")

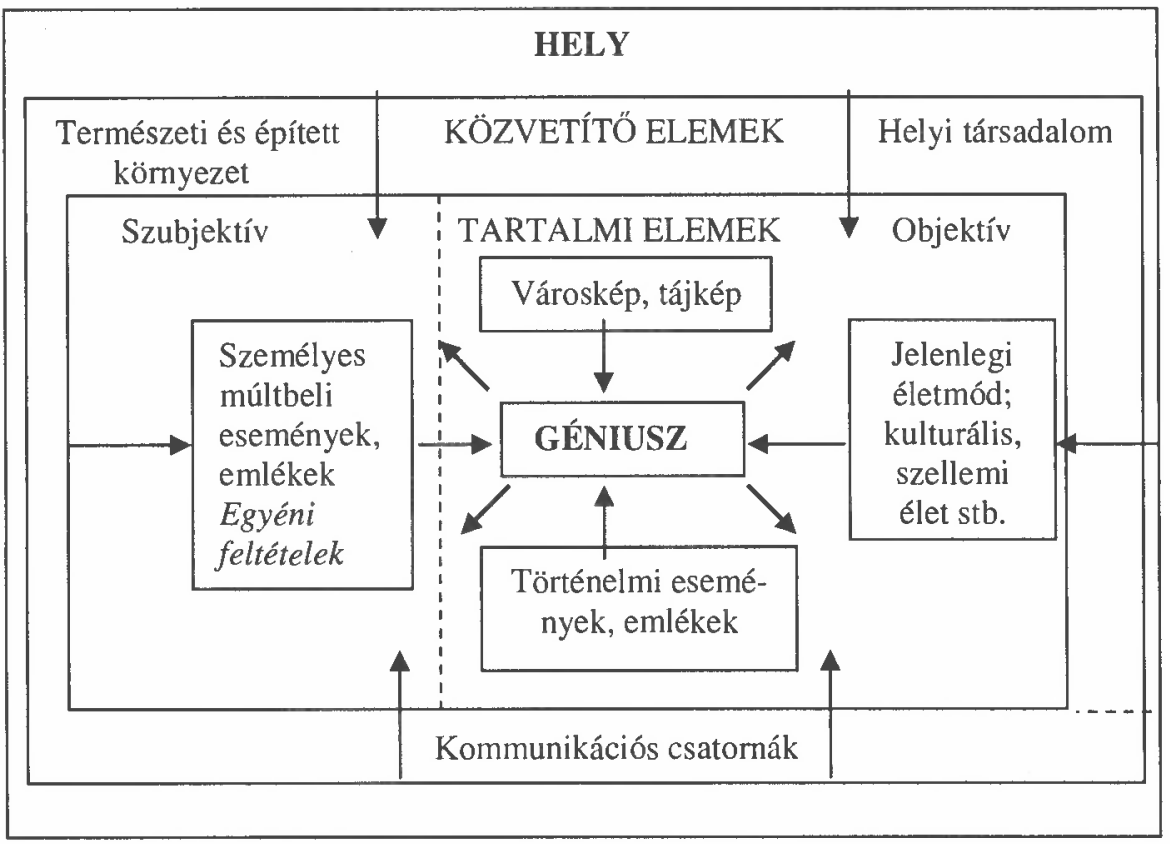

Forrás: Saját szerkesztés.

Végül az összegzés összefoglalásaként definíciót közlünk a hely szelleméröl:

A hely szelleme olyan dinamikusan változó, természeti vagy épitett környezeti helyekröl kisugárzó, az észlelö számára csak ott, helyben átélhetö transzcendentális, alkotó, teremtó eró, amelynek hordozó, közvetítö elemei a természeti és épített környezet, a kultúrtáj, a helyi társadalom, és többnyire közvetetten az információkat továbbitó kommunikációs csatornák. Alapvetö objektív elemei a történelmi ismeretek, emlékek, mint a helyben valaha élt emberek, illetve megtörtént fontosabb események, tudati, tárgyi és írott emlékei, forrásai, illetve a jelenlegi településkép, a 
helyi társadalom jelenbeli életmódja, életrendje, szokásai, de lehetnek szubjektív egyéni elemei is ( 1 . ábra).

\section{A hely szelleme a terekben}

A hely szelleme olyan fogalom, amely kiemeli a helyek egyediségét, hiszen két helynek elméletileg nem lehet ugyanolyan géniusza. A regionális tudomány viszont a helyeket alapvetően nem egyedi elemekként értelmezi, hanem általános térelemekként. A helyekből, mint térelemekböl épülnek fel a terek, relativista térfelfogásban a tér a helyek egyenlötlensége és rendezettsége (Nemes Nagy 1998).

A regionális tudomány a tereket alapvetöen a térelemek jellege, a tér észlelése és a terek mérete alapján osztályozza. A térelemek jellege alapján meghatározott terek az objektív terek, hiszen ezek felépítése független az észleló egyéni tulajdonságaitól, elméletileg tehát az objektív terek minden észlelỏ számára azonosak. Az objektív terek vizsgálatában tehát ki kell zárnunk a genius loci szubjektív elemeit.

Alapvető továbbosztályozási szempont az objektív tereken belül az anyagi és a nem anyagi, vagyis szellemi terek megkülönböztetése. Elöbbi tértípus alatt érthetjük azokat a tereket, amelyek anyagi - szemmel látható, kézzel fogható - elemekböl épülnek fel. E különválasztás szerint a hely szellemének alkotóelemei közül az anyagi terekben szerveződnek az épített környezet és a természeti táj egységei, míg a történelmi, a kulturális elemek, az egyes helyi közösségek életmódja, szellemi élete stb. a szellemi terekben. Maga a szellemi tér is tekinthető egységesnek, ezt a géniusz fogalma megengedi, sőt megköveteli. Ezért az elemeken túl, azokat félretéve felfogható a nooszféra, mint az a tér, ahol a szellemiség terjed, alakul, formálódik. (A nooszféra értelmezése kettős lehet: egyfelől érthetjük alatta a társadalmilag átalakított bioszférát, de mint utóbbi eset is mutatja a szellemiség, a tudati tartalmak terét is.) A hely szellemét így az anyagi és a szellemi terek szoros összekapcsolódásaként is tekinthetjük.

Másik szempont, amikor az objektív tereket külső és belső terekre osztjuk fel. A hely szellemének elsődleges jegye a külső térhez kötöttség, a lokalizáltság. Adott szellemiséget, adott jegyeivel, tulajdonságaival csak azon az adott helyen érezhetjük. A genius loci tartalmi elemei mind-mind egy helyen és pontban fejtik ki bizonyos hatásukat.

A belsö terek egyszerüen szemlélve különbözö dimenziók, értékduálok mentén szerveződnek (Nemes Nagy 1998). A szakrális tér dimenziója így lehet például a szent-profán értékduál, vagy különbözö, sokkal bonyolultabb, értékduálokkal le nem írható valláselméleti dimenziók. De ugyanígy elméletileg beszélhetünk a kultúra, s azon belül a különböző képzőmüvészetek, az építészet, az irodalom, a tradíciók, szokások, gondolkodástípusok stb. belső tereiröl. Ezekhez konkrétságuk, részletezettségük miatt már alig-alig találhatók rendező dimenziók, nemhogy értékduálok. (Elméletileg értelmezhetô a történelem, a történelmi események belső tere is, amelynek egyik dimenziója maga az idö - a dolgok önmagával való nem azonossága - végtelen pólusú viszonyítási tengelye, amit tovább tagol a léptékek rendszere: 
pl. világ-, nép-, népcsoport-, közösség-, család-, személyes történelem.) De mint emlitettuik, a szellemi tér, a szellemiség tere belső térként is értelmezhetö, amelynek térelemeiként az egyes géniuszok foghatók fel.

A különböző szellemi tartalmak, társadalmi szférák belső terei vagy az adott hely egyes objektumai, vagy az ott élő helyi társadalom által lokalizálódnak (Nemes Nagy 1998). A történelmi események egyik lényeges tulajdonsága szintén a helyhez kötöttség, a lokalizálhatóság. Így a szellemi tartalmak szféráinak egymásra épüléseként, egymásra hatásaként is magyarázhatjuk a genius locit.

Az egyes helyek géniuszai, szellemiségei természetesen hasonlíthatnak egymáshoz. Nagyon valószínúnek tünik, hogy az egyes társadalmi szférák belsö tereiben tapasztalható közelségek, vagyis hasonlóságok párosulnak a földrajzi térbeni közelséggel, tehát az egyes helyek szellemisége földrajzi egymásmellettiség esetén több rokon vonást mutat. Ezt a tézist felboríthatja például az egyik „hordozó” elem, a társadalom mobilitása, amely az utóbbi évtizedekben egyre erősebb a globalizációs folyamatok hatására.

A hely szelleme függ az észlelö szubjektumától is. Az észlelök érzékszerveinek müködési sajátosságai, s maga az észlelő egyéni tulajdonságai folytán némileg máshogy érzékelhetik a teret. Ez a felismerés a szubjektív terek fogalmára világít rá. Ennek eredményeképpen az észlelés során az ún. objektív terek is szubjektív jegyeket kapnak (Nemes Nagy 1998). A különböző észlelt terek közötti különbségek azonban a hely szellemének objektív tartalmi elemei esetén minden bizonnyal nem annyira nyilvánvalóak, mint a szubjektív elemek esetén.

\section{A hely szelleme és a modern földrajzi irányzatok}

E fejezetben a genius loci fogalmát el szeretnénk választani a hasonló jelentésü „sense of place” és a helyimage kifejezések jelentéstartalmától. A kérdéskör első áttekintésre bonyolultnak tủnik, azonban az egyes fogalmak egzakt meghatározásával meglelhetők a lényeges különbségek a számos átfedés mellett. A felsorolt fogalmak mentén tovább haladva a városmarketing tevékenységével is több összefüggés tárható fel.

\section{"Sense of place"}

Elörebocsáthatjuk, hogy az angolszász behaviorista földrajzi irodalomban használatos ,sense of place" kifejezés jelentése hasonló a genius lociéhoz, de nem azonos azzal.

Mielött a fogalom konkrét tárgyalására térnénk, néhány megjegyzést szeretnénk tenni a magyarra fordítással kapcsolatban. Ugyan magyar szakirodalomban nem találkoztunk a fogalommal, csupán könyvtári katalógusban, hiányos tapasztalatunk alapján is azt mondhatjuk, hogy a ,sense of place" kifejezést a mechanikus lefordítások helyett, mint a helyröl való érzés, helyérzékelés, a hely érzékelése, helyérzet stb. lefordítható akár - sokkal frappánsabban - hely szellemének is. 
A fogalom tartalmának megismerése után azonban rögzítenünk kell, hogy e megoldás elvetendő, ezért dolgozatunkban a hely érzete, helyérzet kifejezéseket fogjuk használni.

A hely szelleme - „sense of place” fogalompáros jelentését tekintve azonban nem csak a befogadó magyar nyelv tekintetében vannak problémák, hanem magában a kibocsátó országban is. Johnston et al. (1994) ugyanis két meghatározást közöl a „sense of place”-rỏl, amelyek közül az egyik akár a genius loci, de a helyimage meghatározása is lehetne: Egy hely benső, lényeges karaktere, tulajdonsága. Számos helyet ugyanis megkülönböztetnek, emlékezetesnek tartanak egyedi fizikai karakterük, ,elképzelhetőségük” vagy jelentős eseményekhez való kapcsolódásuk, ismeretlen szellemi vagy mitikus tartalmuk révén. Olyan példákat hoznak, mint az Ayers Rock vagy Csernobil, amelyekkel kapcsolatban erös érzései vannak sok embernek, még ha nem is jártak ott. Véleményủnk szerint ezen utolsó félmondat árulkodik arról, hogy ez mégsem a hely szelleme, annak érzékeléséhez meghatározásunk szerint ugyanis ott kell lenni az adott helyen. Eszünkbe juttatja azonban az image fogalmát. A megfogalmazás ennek jelentéséhez is nagyon-nagyon közel áll. Erról azonban késöbb lesz szó.

Induljunk ki Johnston et al. (1994) második meghatározásából. E szerint a mindennapi életben az egyének és a közösségek tapasztalataik, emlékeik, szándékaik szerint erös kapcsolatot fejleszthetnek ki a helyekkel. A legkézenfekvőbb ilyen kapcsolódás a ,hely, mint otthon” érzése. Általában az emberek fizikailag is kifejezésre juttatják a helyhez való ragaszkodásukat. Így szimbolikus rendszereket építenek fel, amelyek növelik a helyek különbözöségét. Összegzö magyarázatukban a városimage alakítással, a posztmodern építészettel kapcsolják össze a „sense of place" fogalmát, amely jelzi számunkra a rengeteg összefüggést és bonyolultságot, amely témánkat jellemzi.

Rose (1995) szerint a helyérzet kifejezi, hangsúlyozza, hogy a helyek fontosak az emberek számára, hogy jelentésük, érzelmi töltésük van, hogy fontos helyet kaphatnak identitásunk kialakulásában is. A helyérzet folyamatos fejlödésben van, áthatja mindennapi életünket. A helyérzet lehet nagyon személyes, de sokszor társadalmi, kulturális, gazdasági viszonyok alakítják. A helyérzet különböző módon kapcsolódhat az identitáshoz. Egyrészt jelenthet a hellyel való azonosulást, továbbá a hellyel való szembenállást, de a hely lehet irreleváns is az identitás szempontjából. Rose tehát sokkal szorosabbra füzi a kapcsolatot a helyérzet és identitás között, így a hellyel való azonosulásról szól, míg Johnston csupán a helyhez való kapcsolódásról beszélt.

A helyérzet is kialakulhat különböző térségi szintek esetében: város, régió, ország, kontinens, vagy az ún. „világpolgárok” esetében akár a föld is szóba jöhet, mint az identitás egyik alapja.

Rose felhívja a figyelmet, hogy ugyanazon a helyen más csoportoknak más helyérzete alakulhat ki. A helyérzet jelentés-magyarázatait három csoportba sorolja.

Egyfelöl a helyérzet tekinthetö egy természetes emberi tulajdonságnak, a helyhez való tartozás igényének következményeként. Ezt territoriális ösztönnek, egyfajta 
túlélési stratégiának is magyarázzák. Másrészt a helyérzet tekinthetö a hatalmakat megalapozó rendszerek szüleményeként is. Ez egyfajta kulturális magyarázat. A kulturális különbségek tudatosodása fokozza a helyérzet kifejlödését. A különbözöségeket észlelỏ közösségek jelezni akarják ezt az általuk elfoglalt helyek kisajátításával, amely tovább erősíti a különbségeket. Ezeket térbeli határok meghúzásával is kifejezik. A határok pedig meghatározzák, hogy kik vannak belül és kik kívull. Így párhuzamot lehet vonni a helyérzetek és a társadalmi egyenlötlenségek között. A helyérzet pedig eredménye lehet a gyarmatosításnak, az imperializmusnak, mint a hatalmak megalapozó rendszereinek. A helyérzet tehát függ a társadalmi erőviszonyoktól is. Harmadrészt a helyérzet az identitás kifejezésének, kommunikálásának, politikájának eredményeként is magyarázható. E magyarázat kiemeli a helyérzet szubjektivitását, az érzelmi dinamika jelentős szerepét. Újra csak fontosak a határok, nem csupán azt mondják meg, hogy ki hova tartozik, hanem azt is, hogy hova nem. A különböző társadalmi csoportok, kultúrák nem saját magukban láthatóak, hanem a megfigyelő identitásának szemszögéből. Ez a másság érzése. Ez nem tiszta és logikus, hanem tele van érzelmekkel, fantáziákkal, félelmekkel, vágyakkal. Az identitás politizálása során a másik sokszor a társadalmilag marginalizálódott, a gyenge, a munkásosztály, a fekete, a periférikus stb. szerepében jelenik meg.

Eyles (idézi Holt-Jensen 1999) négy fajtáját különbözteti meg a helyérzeteknek. Közömbös helyérzet, társadalmi helyérzet, amely a társadalmi kapcsolatokon alapszik, instrumentális helyérzet, a helyek funkcionalitása szerint, végül nosztalgikus helyérzet, amely a helyi történelmi örökségre épít. Tehát külön-külön tárgyalja az egyes szférákban található helyek helyérzeteit.

Mindezek ismertetése után elérkeztünk ahhoz a ponthoz, hogy elválasszuk egymástól a hely szelleme és a hely érzete kifejezések jelentését. Ehhez Holt-Jensen (1999) munkáját hívhatjuk segítségül. Holt-Jensen felhívja a figyelmet, hogy a „sense of place"-t gyakran szinonimájaként értik a genius locinak. Szerinte helyénvalóbb a helyérzetet a hely szellemének tudatosodásának érteni, illetve egy képességként, amely az egyének birtokában van, mintsem a környezet tulajdonsága.

A helyérzet fogalma tehát az identitás kialakítása szemponjából kapcsolódik a helyekhez. Az elöbbi megfogalmazás, miszerint a helyérzet a hely szellemének tudatosulása, magunkévá tétele frappáns, de nem pontos. Véleményünk szerint nemcsak a hely szelleme tudatosodik bennünk, hanem a hely image-e is - és inkább az-, ami szintén hasonló jelentésủ a genius loci fogalmához (lásd a következỏ fejezet).

A helyérzet - mint ahogy Holt-Jensen is idézi - nem a helyekhez kapcsolódó fogalom, hanem az egyénhez, a közösségekhez. Minden egyes hellyel kapcsolatban kialakulhat az emberben egy érzés. Számos hely így részt vállal identitásunkban vagy azáltal, hogy azonosulunk vele, vagy azáltal, hogy nem. Lesznek olyan helyek is, amelyekkel nem tudunk mit kezdeni identitásunk szempontjából. Ha két népcsoport érzi ugyanarról a helyröl, hogy az az ö lakhelye, nemcsak a két közösség fog megküzdeni egymással valamilyen fronton, hanem kettőjük helyérzete is egymásnak feszül majd. 
Elmondható, hogy az identitás kutatása tudományok szerte meglehetősen széles körü, és maga a fogalom is ,,agyonhasznált”, a hazai földrajzi kutatásokban azonban, mint önálló kutatási téma ritka. A városimage vagy a mental map pedig újabban a térségi kutatások során kerül elő (Cséfalvay 1990; Glatz 2000). Az identitás kutatásában elsỏdlegesen hivatott pszichológia látókörébe a hely pedig alig-alig kerül bele, marginális szerepet játszik (Fröhlich 1996; Pataki 1997a; Sillamy 1997; Gereben 1999).

A szociálpszichológia előkészítőjének, ösztönzőjének tekintett nemzetkarakterológiák - amelyek a második világháború elött a faji ideológiák kiszolgálóivá lettek - sem a földrajzi tér vizsgálatára helyezik a hangsúlyt, hanem afféle néplélektant mủvelnek. Manapság közelebb állnak a kulturális antropológiához és a sztereotípiakutatáshoz (Pataki 1997b; Hunyady 2001; Miskolczy 2001).

\section{A hely szelleme és a település-image}

A település- vagy városimage kutatások a behaviorista vagy kognitív földrajz tárgykörébe tartoznak. Ezek a kvalitatív forradalommal jutottak el hazánkba is. A földrajz a pszichológiával talált bennük közös kutatási területet. A településimage vizsgálatok egyik alapját az a felismerés adta, hogy az ember sohasem a valós tér, hanem annak benne élő szubjektív leképeződése - a mentális tér - alapján mozog, cselekszik a térben (Lynch 1979; Cséfalvay 1994; Tiner 1996; Nemes Nagy 1998).

Az image vagy imázs - magyarul kép, hírkép, benyomás stb. - Kovács (2001a, 73) megfogalmazásában ,egy személlyel, dologgal, térrel stb. kapcsolatban az ember tudatában kialakult kép, a róla alkotott ítélet és elöítélet összessége. Az image nem esik egybe szükségszerüen a tényekkel, jelentősen formálják a külső tényezők (pl. sajtó, tv) is." Az image alakító tényezői a személyes tér használata közben szerzett élmények, benyomások, érzelmi alapú értékítéletek, tapasztalatok a pihenéssel, a vásárlással, a barátok, rokonok látogatásával, a munkahellyel kapcsolatban, illetve az ismert helyekröl való szóbeli információk, közvetlen élmények, továbbá a könyvek, sajtó, filmek, rádió, tv stb. útján szerzett ismeretek. Egyáltalán nem biztos, hogy az image egybeesik az objektív valósággal (Cséfalvay 1994; Probáld 1995; Kovács 2001 a; Asworth-Voogd 1997).

A helyek image-ének kialakulásában természetesen nem elhanyagolandók az egyén személyes tulajdonságai, kulturális háttere, iskolai végzettsége, gondolkodásmódja stb. - csakúgy, mint azt a hely szelleme esetében láthattuk.

Az image kialakitása a szubjektív szürőn keresztül az információk begyűjtésével kezdödik, majd az egyén rendszerezi azokat, és kialakít egy gondolati képet. Ennek szellemében történik aztán a döntéshozatal, s a cselekvés. Az image fajták a hely szelleméhez és a helyérzethez hasonlóan többféle térségi szintre kialakulhatnak, így beszélhetünk mikro- (lakás, ház), mezo- (szomszédság, település) és makrotérségi (tájegység, régió, világ) image-rỏl (Tiner 1996; Asworth-Voogd 1997).

Az egyes helyimage-ek közvetlenül, alig tudatosultan részt vesznek az ember mindennapi cselekvéseinek, térhasználatának kialakításában. Az aktuális egyéni 
szükségletek és vágyak megszabják a motivációt, amely alapján az egyén választ a rendelkezésre álló lehetőségek közül. A lehetőségeket befolyásolják a helyimageek, amik összevetésre kerülnek az egyén preferenciáival, elvárásaival. Végsö lépés az értékítéletek kialakítása, majd a döntés. Az image-ek állandóan formálódnak. Az egyén a megismerése, észlelése során válogat a valóság egyes objektumaiból, amelyekből a fejében kognitív séma keletkezik. E séma némileg irányítja az észlelés folyamatát, a megismert valóság pedig folyamatosan módosítja azt (AsworthVoogd 1997).

A helyimage nem egyenlő a mental map-pel. Az csak formája az image vizsgálatának. Az image sokkal több, mint egy térkép. Az emberben egy helyröl kialakult szubjektív kép tele van - a hely szelleméhez hasonlóan - érzelmi elemekkel, érzésekkel, várakozásokkal, elöítéletekkel. Ezért az image leginkább verbális úton fejezhetö ki. Viszont, mivel a helyek a tér elemei, tehát térbeliek, a tudati kép, az image térképi formát is ölthet. A tudatban kialakult „térképet” vizsgálja a mental map kutatás, vagy kognitív térképezés. (A kognitív és a mentális térkép fogalmakat gyakran szinonimaként használják. A szakirodalomban elöfordul azonban a jelentésbeli szétválasztás is. Tiner [1996] az elöbbi alatt az emberi tudatban a térbeli valóság gondolati úton leképezett tükörképét, utóbbi alatt pedig a tudati tartalom térképi ábrázolását érti.) A térkép rajzoltatás útján történő információgyüjtés mellett interjúkat is használnak a verbálisan megfogható tartalmak rögzítésére.

A mental map-ek általában tükrözik az egyén kulturális, etnikai stb. hátterét. Az egyes mental map-ek csoport-specifikusak is, tehát jellemzỏek arra a társadalmi csoportra, ahová az egyén tartozik (Asworth-Voogd 1997; Nemes Nagy 1998). A kognitív térkép kialakítása során Cséfalvay (1990) szerint a begyüjtött információkat belső tájékozódási rendszerré alakítjuk, s azokhoz szubjektív tartalmat, jelentést kapcsolunk. A szubjektív jelentéssel felruházott elemekkel azonosulhatunk is, azok részt vehetnek identitásunk kialakításában. E megállapításával viszont - véleményünk szerint - Cséfalvay már a helyérzet fogalmához közelít.

A hazai szakirodalomban egészen érdekes kísérletek is találhatók a mental map, illetve a városimage kutatás területén: Podzer $(2000 ; 2001)$ hasonló célokkal vizsgálta Eger városát versek és régi városábrázolások alapján.

\section{Összegzés}

Még egyszer hangsúlyoznunk kell, hogy a helyimage nem egyenlö a mentális vagy kognitív térképpel. Ellenkező esetben nem lenne nehéz dolgunk a hely szellemével való összehasonlítás során. Alfejezetünk végén azonban már nem csupán az előbb említett két fogalom elválasztását kíséreljük meg, hanem miután most már mindegyiket érintettük, a három kifejezés együttes értelmezését is megtesszük.

Legalapvetőbb különbség a genius loci és a helyimage között szintén az, hogy a hely szellemét csak helyben lehet érezni, míg az image akkor is elöhívható, ha éppen nem az adott faluban, városban tartózkodunk. Sỏt, image olyan településről, területröl is kialakulhat, ahol még soha sem voltunk. Kiemelendő továbbả, hogy a 
hely szelleme nagyrészt a történelmiség által meghatározott „erő”, az image jelentésrendszerében viszont kevesebb szerepet kap, sokkal inkább a jelenben létező fogalomról van tehát szó.

Egyszerủen, mint azt már a helyérzet esetében is megfogalmazhattuk volna, a városimage és a helyérzet is ,másból van”. A genius locit erőként definiáltuk, a mi a gondolkodásunkra hat. Előbbi kettő viszont inkább ,gondolatból" van, ami cselekvésünkre hat. Természetesen, mint ahogy említettük is, a hely szelleme is hathat cselekvésünkre. Csakhogy a hely szelleme esetén ez a hatás jóval erősebb, közvetlenebb, jóval tudatosultabb, fogalmazhatunk úgy is, hogy az „emberi gondolkodás magasabb rétegeiben hat”. Míg a helyimage által befolyásolt, azok alapján végzett cselekvések inkább ösztönösnek mondhatók. A hely szellemét - anélkül esetleg, hogy ismernénk magát a fogalmat - fel kell fogni, át kell élni, míg ez a mozzanat a helyimage és a helyérzet esetén elmarad.

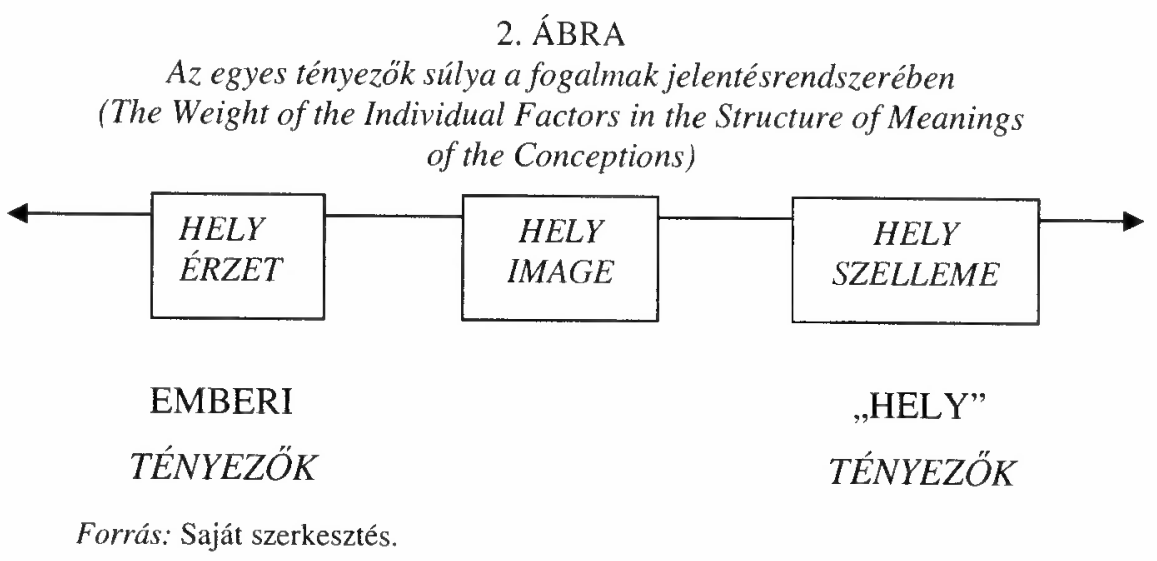

Mindhárom fogalom - a hely szelleme, a helyimage, a helyérzet - a helyröl és az emberröl szól. A hely szelleme tartalmi elemeiben a legtöbb talán az „objektív” „hely” tényezök súlya, míg relatíve a helyérzetben a legkisebb, legtöbb az emberi tényezök szerepe, hiszen az az identitás meghatározásában vehet és vesz részt. A helyimage-t a kettő között érezzük. Természetesen ezekkel a megállapításokkal lehet vitatkozni (2. ábra).

\section{A hely szelleme és a helymarketing}

A helymarketing vagy település- és területmarketing kialakulásának okai egyrészröl a városokon kívül, másrészt a városokon belül keresendők. Előbbiek a szub- és dezurbanizáció, a neokonzervatív gazdaságpolitika általános elöretörése a nyugati demokráciákban, és az annak alapján bevezetett megszorító intézkedések és a globalizáció. Ezek okozataként elsősorban a városokban, azokon belül is a nagyvárosokban és a metropoliszokban léptek fel súlyos problémák, mint a lakosságszám, és annak folyományaként a helyi adóbevételek leapadása, csakúgy, mint a csökkenő állami hozzájárulás, illetve a városok egyéniségének megőrzésére formálódó igé- 
nyek megerősödése, és növekvő globális-regionális városverseny. Részben a globalizáció hatására a fogyasztási szokások is megváltoztak. A városgazdálkodási folyamatok is átalakultak a gazdasági változások következtében: tercierizálódás, az ipar mobilitásának növekedése, a társadalmi, jóléti szolgáltatások és a magánszolgáltatások közeledése révén (Rechnitzer 1996; Asworth-Voogd 1997; Kovács 200lb).

A helymarketing a hagyományos marketingből nőtte ki magát. Magában foglalja tehát mindazokat az eszközöket is, amelyek az utóbbit jellemzik, így a marketing alapelemeit: a piaci elemzést és szegmentálást, a piackiválasztást, a termékdifferenciálást, a promóciót, a termékfejlesztést stb.

A helymarketing a várost, annak egyes részeit tekinti terméknek. Az egyes várostermékek azonban nem függetlenek egymástól. Alapvető különbség továbbá a marketing és a helymarketing között, hogy utóbbi esetben nem történik adásvétel, nem történik meg a tulajdonjogok cseréje, a fogyasztó csupán „használója” a terméknek, sok más társához hasonlóan.

A városmarketing folyamatában tehát külön kell foglalkozni a lehetséges fogyasztói körökkel. Ezek meglehetósen eltérő igényekkel, preferenciákkal, célokkal, feltételekkel stb. rendelkezhetnek az anyagi javak, a városi funkciók, a városi esztétikum stb. területén. Elég a lakosság, a városba érkezö turista, a helyi vállalkozó vagy a külföldi tőkebefektető alaptípusaira gondolnunk (Probáld 1995; Asworth-Voogd 1997).

Itt többek között fontos feladat a várost használók image-einek megismerése. A piacon alkalmazandó marketingstratégiai eszközök - mint a területi, funkcionális vagy a fogyasztásösztönző beavatkozások - közül az utóbbi körébe tartozik, amikor a városvezetés, a várostervezök tudatosan formálni kívánják a város image-ét. A helyimage-ek alakítása a helymarketingnek napjaink egyik legfontosabb eszköze.

Ez csak részben jelenthet konkrét beavatkozásokat, például építészetieket, jelentös a kommunikáció, a promóció szerepe. Fontos a hitelesség, továbbá hogy a városmarketinget folytató települések, illetve térségi szintek összehangolják tevékenységüket, különben semlegesíthetik egymás törekvéseit (Probáld 1995; Kovács 2001b).

A városmarketing eszközeivel azonban nemcsak a hely image-ére hathatnak és hatnak, hanem a helyérzetre és a hely szellemiségére is - még ha ezek a fogalmak benne sincsenek a városmarketing fogalomtárában. Ez természetes is, hiszen mint bemutattuk, a három fogalom szoros kapcsolatban van egymással.

A fentiekben már láthattuk az építészet lehetőségeit, illetve felelősségét a hely szellemének alakításában. Nem vitás, hogy például az épített környezet megváltozásával, de más marketing eszközökkel az egyén helyimage-én túl helyérzetét, így az identitást is formálni lehet (Cséfalvay 1990; Töröcsik 1995).

A hely szellemének történelmi beágyazottsága miatt, annak valóságon alapuló befolyásolására legföképpen a történelmi településeknek van módja. A helymarketing eszközeivel a hely szellemének közvetítő elemei közül elsősorban a kommunikációs csatornák alakítására, bővítésére van módja. Ilyennek véljük a fent említett promóciós eszközökön kívül az olyanokat, mint pl. az emléktáblák, ismeretterjesztó táblák elhelyezése, várostörténeti kiállítások, vetélkedők szervezése. Mindezeken 
túl a város image-ének promóciójában a géniusz kiemelése révén a hely szellemisége közvetlen szerepet is kaphat.

A városmarketing szerepét tehát abban látjuk, hogy elösegítse a hely szellemiségének kibontakozását, az észleló - városlakó vagy idegen - számára megkönnyítse annak felismerését, átélését. Nem pedig abban - mint a helyimage esetében -, hogy alakítsa azt. Végeredményben a hely szellemével való foglalkozás, törődés a helyimage formálás kiegészítőjeként jelenhet meg.

\section{Irodalom}

Asworth, G.J.-Voogd, H. (1997) A város értékesítése. Közgazdasági és Jogi Könyvkiadó, Budapest.

Bakos F. (1994) Idegen szavak és kifejezések kéziszúrára. Akadémiai Kiadó, Budapest.

Baksa P. (2002) Ferenczy Viktor György (1894-1943).- Soproni Szemle. 1. 72-77. o.

Barhta E. (2000) A szakrális táj fogalma a néprajztudományban és a folklorisztikában. - Keményfi R.llyés Z. (szerk.) Tiszteletadús Szabó Józsefnek. Tamulmányok a földrajztudomány témaköreiböl. Debrecen. 109-115. o.

Bánk J. (1997) 3800 latin bölcsesség. Szent Gellért Kiadó, Budapest.

Bánlaky P. (1992) Esztergom, a szent és gyámolithatatlan város. MTA PTI, Budapest.

Berényi I. (200la) Adalékok a városi élettér szociálgeográfiai felfogásához, - Földrajzi Értesítö. 1-4. 143-149. o.

Berényi I. (200lb) A kultúrtáj és -régió, mint kulturális örökség.- Ezredforduló-századforduló-hetvenedik évforduló. Ünnepi tanulnányok Zimányi Verc tiszteletére. PPKE BTK, Piliscsaba. 639-650. o.

Böhm A. (2000) Térségi identitás Magyarországon. - Glatz F. (szerk.) Teriuletfejlesztés és közigazgatússzervezés. Magyarország az ezredfordulón. MTA, Budapest. 111-125. o.

Böhm A.--Táll É. (1992) Pápa a rezisztens város. MTA PTl, Budapest.

Cséfalvay Z. (1990) Térképek a fejiinkben. Budapest.

Cséfalvay Z. (1994) A modern társadalomföldrajz kézikönyve. IKVA, Budapest.

Eliade, M. (1996) A szent és a profán. Európa, Budapest.

Élesztös L. (föszerk.) (1993) Magyar nagylexikon?. VIII. kötet. Akadémiai Kiadó, Budapest.

Fröhlich, W.D. (1996) Pszichológiai szótár. Springer, Budapest.

Glatz F. (szerk.) (2000) Területfejlesztés és közigazgatás-szervezés. Magyarország az ezredfordulón. MTA, Budapest.

Granasztói P.-Pogány F. (1960) Városépítészet. - Garnasztói P. (szerk.) Város és építészet. Budapest. $101-219.0$.

Granasztói P. (1972) Ember és látvány városépitészetünkben. Akadémiai Kiadó, Budapest.

Gereben F. (1999) Identitás, kultúra, kisebbség. Osiris-MTA Kisebbségkutató Mühely, Budapest.

Gerő L. (I984) Magyar müemléki ABC. Müszaki könyvkiadó, Budapest.

Hamvas B. (1988a) Scientia Sacra. Magvetö Kiadó, Budapest.

Hamvas B. (1988b) Az öt géniusz. Életünk könyvek, Budapest.

Holt-Jensen, A. (1999) Geography. History and Concepts. Sage, London-Thousand Oaks-New Delhi.

Hunyady Gy. (2001) A nemzeti karakter talányos pszichológiája. - Hunyady Gy. (szerk.) Nemzetkarakrerológiák. Osiris, Budapest. 7-50. o.

Johnston, R.J.-Gregory, D.-Smith, D.M. (eds.) (1994) The Dictionary of Human Geography. Blackwell Reference, Oxford.

Konrád Gy. (1989) Emlékezés Nyugat-Berlinse, - Tekintet Kulturális Szemle. 10. 7-24. o.

Kovacsics J. (2001) Nemzeti kulturális örökségünk a helységnév. - Falu, város, régió. 5. 3-5. o.

Kovács Z. (2001a) Társadalomföldrajzi kislexikon. Müszaki Könyvkiadó, Budapest.

Kovács Z. (200lb) A marketing szerepe a terület és településfejlesztésben. - Beluszky P.-Kovács Z.Olessák D. (szerk.) A terïlet-és telepultésföldrajz kézikönyve. Ceba Kiadó, Budapest. 144-149. o.

Kubinszky M. (1995) Tíjitépítészet. Mezőgazda Kiadó, Budapest.

Loukaki, A. (1997) Whose Genius Loci?: Contrasting Interpretations of the „Sacred Rock of the Athenian Acropolis"- Annals of the Association of American Geographers. 2. 306-329. o.

Lukovich T. (2001) A posztmodern kor városépitészetének kihívásai. Pallas, Budapest.

Lynch, K. (1979) A város szemléletének struktúrája. - Vidor F. (szerk.) Urbanisztika. Gondolat, Budapest. 537-558. o. 
Mandics Gy. (1996) A genius loci Temesváron. - Simon O. (szerk.) A hely szelleme. A Fonyódi Helikon kisantológiája 12. Fonyód. 50-53. o.

Meggyesi T. (1999) Az égi Jeruzsálem. - Csontos J.-Lukovich T. (szerk.) Urbanisztika 2000. Akadémiai Kiadó, Budapest. 63-73. 0 .

Miskolczy A. (2001) Szellem és nemzet. Napvilág, Budapest.

Mumford, L. (1985) A város a történelemben. Gondolat, Budapest.

Nemes Nagy J. (1998) A tér a társadalomkutatásban. Bevezetés a regionális tudományba. Hilscher Rezső Szociálpolitikai Egyesủlet, Budapest.

Orosz I. (2001) A szellem helye. Új Mandátum, Budapest.

Pataki F. (1997a) Identitás-személyiség-társadalom. - Lengyel Zs. (vál.) Szociálpszichológiai szöveggyüjtemény. Osiris, Budapest. 513-529. o.

Pataki F. (1997b) Nemzetkarakterológia? - Magyar Tudomány. 2. 169-179, o.

Podzer P. (2000) Kísérlet Eger város mentális térképeinek megrajzolására magyar költók versei alapján. - Keményfi R.-Ilyés Z. (szerk.) Tiszteletadás Szabó Jozsefnek. Tanulmányok a fóldrajztudomány témaköreiböl. Debrecen. 185-195. o.

Podzer P. (2001) Eger régi ábrázolásainak városimázst megalapozó fỏldrajzi vonásai (1576-1900) Ilyés Z.-Keményfi R. (szerk.) A táj megértése felé. Tanulmányok a 75 éves Pinczés Zoltán professzor tiszteletére. Debrecen-Eger. 231-249. o.

Pogány F. (1954) Terek és utcák müvészete. Budapest.

Pócs E. (1983) Tér és idö a néphitben. - Etnographia. 2. 177-206. o.

Probáld K. (1995) Városmarketing. - Comitatus. 11-12.3-17., 8-21. o.

Rechnitzer J. (1996) Vázlatpontok a településmarketing értelmezéséhez és kidolgozásához. - Árvai J. (szerk.) A településfejlesztés elmélete és gyakorlata. CEBA, Hatvan. 65-70. o.

Rose, G. (1995) Place and identity: a sense of place. - Massey, D.-Jess, P. (eds.) A place in the World? Places, cultures and globalization. The Open University, Oxford, New York. 87-132. o.

Ryle, G. (1974) A szellem fogalma. Gondolat, Budapest.

Sandercock, L. (1999) Kozmopolisz felé - utópia építés alatt. - Csontos J.-Lukovich T. (szerk.) Urbanisztika 2000. Akadémiai Kiadó, Budapest. 53-59. o.

Sillamy, N. (1997) Pszichologiai lexikon. Corvina, Budapest.

Szabó B. (2001) Vallomás az épített kơrnyezet globális védelméröl. - Falu, város, régió. 6. 10-13. o.

Székelyné Egri Zs. (1979) Az épitett kömyezet védelme. Budapest.

Széky J. (főszerk.) (1994) Britannica Hungarica világenciklopédia. VII. kỏtet. Magyar Világ Kiadó, Budapest.

Tiner T. (1996) Az image-vizsgálatok helye és szerepe a városföldajzi kutatásokban. - Dövényi Z. (szerk.) Tér-Gazdaság-Társadalom. Huszonkét tanulmány Berényi Istvánnak. MTA FKI, Budapest. 117-150. o.

Tokarev, Sz.A. (föszerk.) (1988) Mitológiai enciklopédia II. Gondolat, Budapest.

Tóth Z. (2001) Építészet-városépitészet. Hagyomány és modernizáció. Ponte Press Kiadó, Pécs.

Töröcsik M. (1995) Telepúlés- és területidentitás kialakítása marketing eszközökkel. - Tér és Társadalom. 2. 17-23. o.

Trencsényi-Waldapfel I. (1983) Mitológia. Gondolat, Budapest.

Vekerdi L. (1996) A hely szelleme - a határon innen és túl. - Simon O. (szerk.) A hely szelleme. A Fonyódi Helikon kisantológiája 12. Fonyód. 35-46. o.

\section{THE SPIRIT OF PLACE, SETTLEMENT IMAGE AND SETTLEMENT MARKETING}

\section{FERENC JANKÓ}

The concept "genius loci" is widely used, but it cannot be connected with only one discipline. Beside writings on literature it is also found in the conceptual sphere of postmodern architecture and sociology. This study tries to describe the different types of conceptual approaches, to interpret the phrase "the spirit of place" with the "language" of 
regional science, and to distinguish its meaning from the concepts of behavioural geography "settlement image" and "sense of place".

In the understanding of regional science the spirit of place can be interpreted as a close connection of material and spiritual spaces. In the relation of internal and external spaces the internal space of spirit can also be examined, the spatial units of which are the geniuses.

Unlike the "settlement image" and the "sense of place" the spirit of place can be experienced only in the given place and at the very moment. The meaning of "genius loci" is more transcendental and is more determined by local factors than by subjective ones. 